\title{
Discussion on Problems in Student Management of Private College under New Situation and Its Countermeasures
}

\author{
Zhenpeng Zhao \\ School of Art and Design \\ Huanghe Science and Technology College \\ Zhengzhou, China 450006
}

\begin{abstract}
Under the current new situation, on the whole, student management in private colleges is not very effective. To improve effectiveness of student management of instructors in private colleges, measures should be taken, including optimizing team, changing and reforming idea, improving methods of student management and laying emphasis on exceptional students in order to achieve the goal of good student management.
\end{abstract}

Keywords-private colleges; student management; effectiveness

\section{INTRODUCTION}

Currently, private colleges of our country have developed quickly and become an important part of higher education. The society pays increasing attention to their level in running school. Private colleges face good opportunity as well as serious challenges in development. The characteristics of students enrolled by private colleges decide the difficulties of student management in private colleges. Therefore, it is necessary to think about how to improve the effectiveness of student management of instructors in private colleges.

\section{Factors that Restrain StUdent MANAGEMENT OF INSTRUCTORS IN PRIVATE COLLEGES}

In order to improve the effectiveness of student management in private colleges, firstly, we need to clearly know the factors that restrain student management of instructors in private colleges, so that corresponding countermeasures can be taken to improve the effectiveness of student management. According to the analysis on current situation of student management of instructors in private colleges, there are mainly four factors that restrain the effectiveness of student management in private colleges:

\section{A. The Team of Student Management Is Weak.}

The current student management team in private colleges has some unreasonable factors, mainly including: Firstly, the number is insufficient in private colleges. In some private colleges, an instructor often needs to manage hundreds of students. Besides, instructors in private colleges are often responsible for other administrative management. It greatly restrains the effect of student management. Secondly, the management quality is poor. Most instructors of private colleges are selected from previous graduates. Because most of them are not trained necessary quality in student management such as pedagogy and psychology, they neglect receptivity of students in management. Thirdly, academic research is poor. Private colleges bear heavy burden and have weak quality, so rare academic researches related to student management have been done and it is very difficult to master the newest student management experience. Fourthly, the changes of team are great. Some instructors with poor sense of responsibilities in private colleges don't take student management as lifework. They are eager to become teachers of professional courses or do other jobs after working for one or two years. The frequent changes also influence the effect of student management.

\section{B. Student Management Idea Is Outdated.}

Some universities lack profound understanding of the status and importance of student management. They still follow the traditional management mode that expounds mechanically. This mode is very difficult to get the node of students, let alone train self-education and self-management skills of college students. Meanwhile, some private colleges ignore the overall quality of students. Instead, they blindly follow the open management mode adopted by some comprehensive universities. As a result, they let students develop freely, which leads to the negative effects that the style of study declines and student management becomes chaotic.

\section{Student Management Mode Is Single.}

At the initial stage, private colleges only refer to student management mode of public universities instead of forming mature and systematic management idea and system that suits the characteristics of their own. Currently, the student management idea of some private colleges is still lagging. They think student management is the responsibility of student management educators and student work system of universities. The concept is wrong and has resulted in harmful effects such as the student management separates from teaching in some private colleges 


\section{Student Management Methods Are Backward.}

Student management workers in private colleges pursue simple methods in work and only fulfill the task assigned by superior. They pay attention to the form and fulfillment of tasks instead of effects and communication with students. The methods are unscientific, so that it is inevitably difficult to achieve good work efficiency.

\section{COUNTERMEASURES TO STRENGTHEN THE}

\section{EFFECTIVENESS OF UNIVERSITY STUDENT MANAGEMENT}

After analyzing problems in student management of private colleges at present, countermeasures can be proposed to improve effectiveness of student management in private colleges.

\section{A. Optimize Student Management Team}

Build a high quality team of student management to provide organization guarantees, which is the basis to improve effectiveness of student management in private colleges. The following ways can be adopted by private colleges to optimize the student management team. (1) Enrich student management team: Private colleges should provide management staff according to reasonable proportion such as 1 to 200 to solve the problem of insufficient personnel in student management. They can also employ some personnel that have master degree and major in pedagogy and psychology related to student management to improve the overall quality of student management team. (2) Strengthen learning and training: Private colleges should strengthen the training for student management personnel and insist on the training principle of "walking out" and "bringing in" to let them continuously absorb advanced theories and experience in student management. (3) Pay attention to scientific research on student management: Private colleges should encourage student management personnel to attach importance to academic research on student management work and unceasingly research new situation, analyze new problems and summarize new experience as well as improve student management level. (4) Build corresponding incentive mechanism: Private colleges should regularly select and praise advanced student management personnel at the same time build corresponding assessment and promotion system to enhance the enthusiasm of them.

\section{B. Change Student Management Idea}

Student management personnel of private colleges should use advanced idea to guide student management. (1) Set up the student first idea: Student management workers should respect students, including their personality, individuality and basic rights and use people-oriented management idea in work. Student first is to awake and respect students' personality. The real student management is student first, lets students experience the happy school life, successful learning and pure friendship with classmates and train their positive attitude towards life, correct value judgment and rich thoughts through education activities. Student-oriented management needs to recognize principal status of students in school, understand, respect and serve them. College students need the school to provide more convenient and humanized service for them.
They pay more attention to their lawful rights and interests. It requires applying humanized management in higher education management. Humanized management emphasizes starting from students' requirements, taking them as equal main body and service object and centering on students' interests to implement the management. If humanized management is applied to higher education management, the boundary between controllers and subordinates will be fuzzy. The common point between them will be emphasized and enlarged. They will form the same interest and objective to achieve the management goal powerfully. (2) Set up the idea of democracy: Private colleges should give sufficient opportunities for selfmanagement of students. With the development of society, on one hand, students have increasingly strong will to equally participate in management of things related to their interests, so it is necessary to strengthen democratic idea in student management to reveal the spirit of humanistic management; on the other hand, thoroughly change the tendency of "administration" and "institution" of university student management to realize "marketization" of student management and establish good atmosphere and effective educational method according to idea, psychology and characteristics of college student to provide services for students. (3) Set up the idea of legal system: Private colleges should enhance the awareness of observing law and discipline. In student management, enhancing the awareness of the law is to fully respect and protect lawful rights of college students. Student management in private colleges should implement legal concept, fully respect students' lawful "right of claim", proper "right of choice" and reasonable "right to be informed" to guarantee rights of students.

\section{Innovate In Student Management Mode}

The educational management of college students is a systematic engineering requiring all staff participation. Private colleges must firmly establish the idea of whole staff education and use all available educational resources and consider from the complicated, penetrative and long lasting educational management to build comprehensive, three-dimensional, longterm and effective educational management mode for college student management and form new situation that the society, school and family participate in, concern and support college student management jointly. Instructors, course teachers and parents of students are the most direct and effective resources in college student management. Therefore, it is the inevitable choice of private colleges to build student management mode that integrate instructors, course teachers and students' parents. (1) Adjust the original student management mechanism. Nowadays, student management in most universities adopts the same mode, namely the management mechanism consisting of instructors and class teachers under the leadership of students' affairs office, general Party branch, party branch, Youth League Committee and Youth League general branch. The mode is hierarchical and the system can operate orderly by depending on obeying orders. Student management loses vigor. Private colleges should fully stimulate enthusiasm of grassroots student management staff in the existing mechanism and empower them to form innovative and vigorous system. (2) Build mechanism for instructors and course teachers to communicate. Necessary 
communication lacks between student management staff and course teachers in private colleges, so student management staff cannot know about overall situation of students comprehensively. Private colleges should strengthen the communication between student management staff and teachers. (3) Build mechanism for instructors and parents of students to communicate. University instructors should improve records of student family. It is the basis to build communication mechanism between instructors and parents of students. Instructors communicate with parents on students' situation to promote the education.

\section{Improve Student Management Methods}

Private colleges should endeavor to improve the current student management method and use student-oriented, democratic and legal idea to manage students. (1) Strengthen the construction of student management system. Building a sound student management system that fully embodies theory on school management and practice is the premise to ensure healthy development of private colleges and achieve the education goal. Private colleges should research schoolrunning characteristics of their own thoroughly, seriously refer to and learn mature experience of other related colleges and continuously strengthen system construction as well as standardize student management. In specific system construction, private colleges should unceasingly improve the system, take the relationship between system executors and the target of execution into full consideration and carry forward democracy and take advice from students, teaching staff and other departments. Meanwhile, provide procedure and platform for students to safeguard legal rights to make the system more standard, stable and operational. (2) Fully give play to the role of student cadres. Instructors of private colleges should select high quality students with public trust as student management assistant to manage students through instructor and class committee to embody the democratic principles of student management. (3) University instructors need to change roles. Student management is an art that needs to be carried out scientifically and creatively. The property and characteristics of instructor's work determine they play diversified instead of single role. Like actors, instructors need to play many roles according to different requirements. Instructors should play the following four roles scientifically: good teacher and helpful friend (flag on politics, model on behavior, helper on learning and intimate friend in life), life coach (guide on students' life path), leader (leaders on students' growth), instructor and server. Instructors of private colleges should explore, develop and improve themselves actively in practice, update idea and reposition as well as improve accomplishment. Only in this way can they adapt to the mission and do well in student management.

\section{E. Lay Emphasis on Special Students}

The important responsibility of university student management is to serve students and help them to overcome difficulties in learning and life. Students from poor families, students with difficulties in employment and psychological problems should be served. University student management should further improve the mechanism of social assistance and support, open green channel and guarantee the admission of poor students. To make channels such as student loan, scholarship and student subsidies unblocked, universities can contact far-sighted personage to help the poor, organize activities and raise funds to help poor students and encourage university students to start a business independently or open tertiary industry, provide opportunities for them to realize parttime-work and part-time-study, in order to let them learn with confidence. The problem of difficulties in employment is prominent among college students. The thoughts of some students become unstable because of this. It brings unstable factors for student management. Student management should guide college students to change the traditional employment idea and choose an occupation that adapts to the change of market economy. Universities can actively contact employment unit to recruit graduates of related majors in school to relieve employment pressure of students. Diversification and the acceleration of life pace make many students appear psychological problems. It becomes a new content of student management. Psychological consultancy organization should be established to serve psychological health of students. It is also important to focus on students' psychological development, psychological fluctuation and track and prevent timely to guarantee healthy development of students' psychology.

\section{CONCLUSION}

To sum up, private colleges need to explore ceaselessly in practice, pay equal attention to student management team, idea, mode and methods as well as the focus on special students, make up for deficiencies and strengthen weak links, so as to improve the effectiveness of student management. All in all, student management should conform to demands of social development, care for students and timely and effectively update educational idea, strengthen the awareness and continuously intensify the dominant role of students, improve corresponding management system and enhance construction of student team as well as timely solve psychological problems existing in the growth of students. In this way, student management departments can better serve students, help students to become useful persons and ensure the construction of harmonious campus, promote universities to continuously adapt to the era development and let each student effectively take the responsibility to construct our country.

\section{REFERENCES}

[1] Huang Wei. Research on Application of Human-based Management in University Student Management [J], New West (theory edition), 2014, No.29407:114

[2] Wang Ping. Research on Student Management in Universities [J], Education Exploration, 2014, No.28010:89-90

[3] Xiang Qun. Role of Instructors in Student Management [J], China Science and Technology Information, 2011(2)

[4] Chen Qimin. Problems in Student Management of Private Colleges in China and Countermeasures [J], Fujian Higher Education Research, $2010(6)$

[5] Wang Xiaoyan. Research on Problems Faced by Student Management in Universities and Countermeasures [J], Manager' Journal, 2015, $35: 284$. 